\title{
Context conditions factors for lifelong learning in nursing education
}

\author{
Shahla Mohammadzadeh Zarankesh ${ }^{1}$, Parivash Jafari², Akhtar Jamali ${ }^{3}$, Mohammadali Hosseini ${ }^{4}$ \\ ${ }^{I}$ PhD Candidate of Higher Education Administration, Department of Management and Economy, Islamic Azad \\ University, Science and Research Branch, Tehran, Iran \\ ${ }^{2}$ Associated Professor of Educational Administration, Department of Management and Economy, Islamic Azad \\ University Science and Research Branch, Tehran, Iran \\ ${ }^{3}$ Assistant Professor of Social Medicine, Iran University of Medical Sciences and Health Services, Tehran, Iran \\ ${ }^{4}$ Associate Professor of Higher Education Administration, Department of Rehabilitation Management, University of \\ Social Welfare and Rehabilitation Sciences, Tehran, Iran
}

\begin{abstract}
Background: Nurses need to be lifelong learners to provide care, efficiently, and apply the art of care, in a context of rapid change in knowledge and technology. Life-long learning is an indicator of professionalism for health care professionals. A study of creating a lifelong learning culture for nurses is a necessity. This study aimed to identify the basis of lifelong learning for nursing education in the field of "education system". Materials and methods: This study was based on grounded theory approach and purposeful sampling method with open-ended semi-structured interviews on 19 nursing scholars and professors who had a PhD in nursing and medical education. According to Strauss and Corbin's method, the data were collected, analyzed and interpreted simultaneously and analyzed by continuous comparative method for validation and the acceptance of data a collaborator check and external observer were used.

Results: By analyzing the viewpoints of participants, the basis of lifelong learning in the field of educational system had three main areas, including "policies, curricula and assessment system, and teaching-learning methods". They became the main category of characteristics in the educational system.

Conclusion: Regarding the necessity of education with the a lifelong learning approach for nursing students, policy makers in the field of health and nursing, planners and administrators of nursing schools can develop effective strategies with the aid of factors identified in this study.

Keywords: Lifelong learning, Educational system, Context conditions factors, Nursing education, Grounded theory.

Cited as: Mohammadzadeh Zarankesh SH, Jafari P, Jamal A, Hosseini MA. Context conditions Factors for Life Long Learning in Nursing Education. Medical Science Journal of Islamic Azad University, Tehran Medical Branch 2019; 29(4): 357-369.

Correspondence to: Parivash Jafari

Tel: 09121833294

E-mail: pjaafari@yahoo.com

ORCID ID: 0000-0003-2916-8870

Received: 28 Nov 2018; Accepted: 6 Mar 2019
\end{abstract}


مجله علوم يزشكى دانشگاه آزاد اسلامى

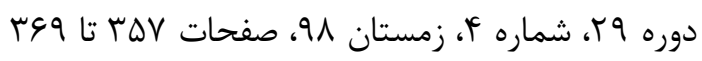

Original

Article

\section{عوامل زمينه ساز يادَيرى مادامالعمر در آموزش يرستارى}

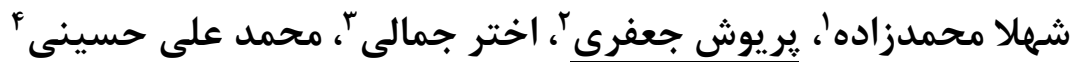

'دانشجوى دكتراى مديريت آموزش عالى، دانشكاه آزاد اسلامى واحد علوم و تحقيقات، تهران، ايران

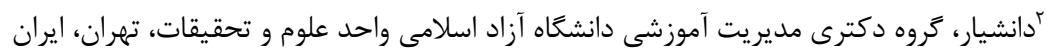

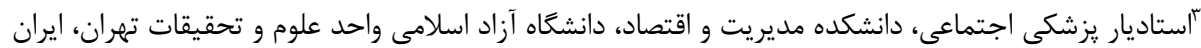

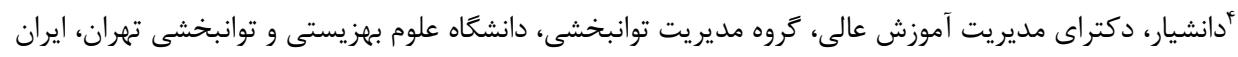

جـكيده

سابقه و هدف: برستاران براى ارائه مراقبت كارآمد و به كار بستن هنر مراقبت در شرايط تغيير سريع دانش و فن آورى، نياز دارند كه

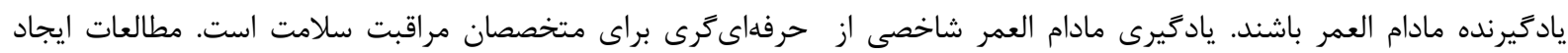

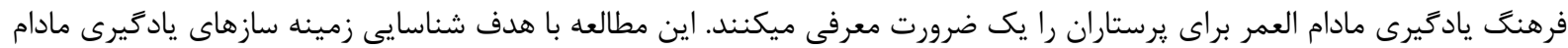

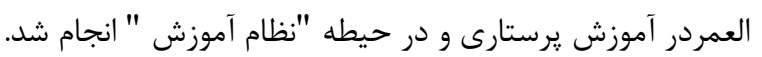

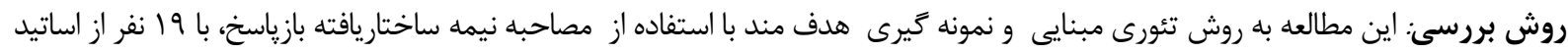

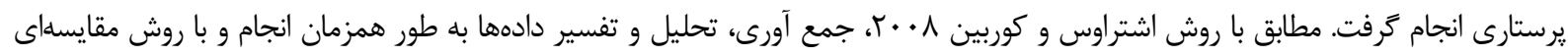

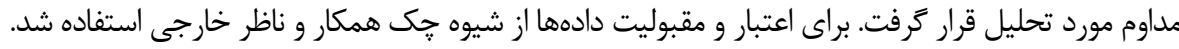

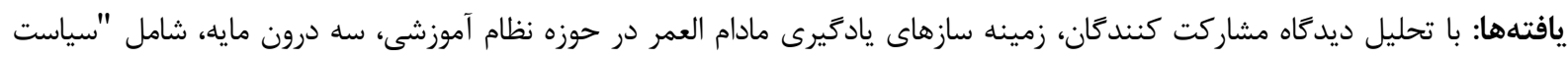

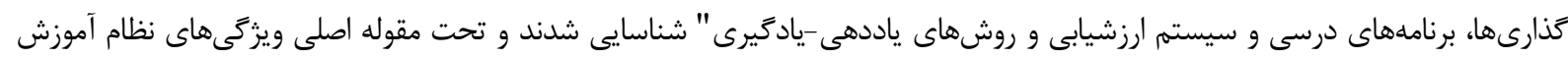
جاى كرفتند. نتيجه گيرى: آموزش يرستاران با رويكرد يادكيرى مادام العمر، نياز به حمايت كسترده از طرف سياست كذاران و برنامهريزان حوزه بهداشت و

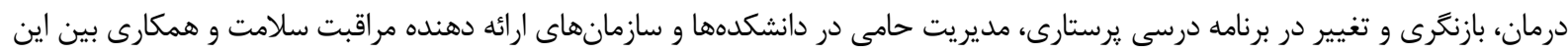

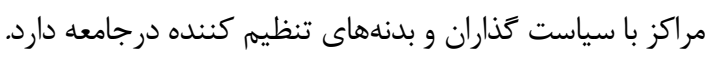

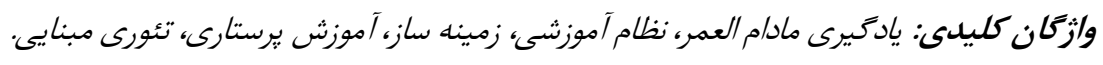

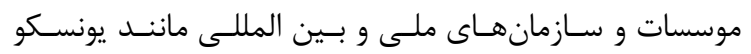
مقدمه (UNESCO)

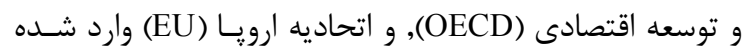

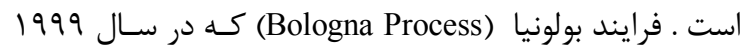

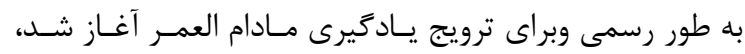

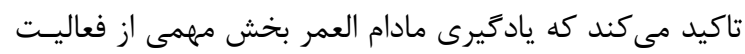

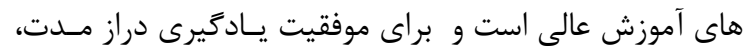

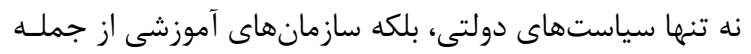

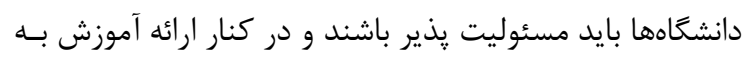

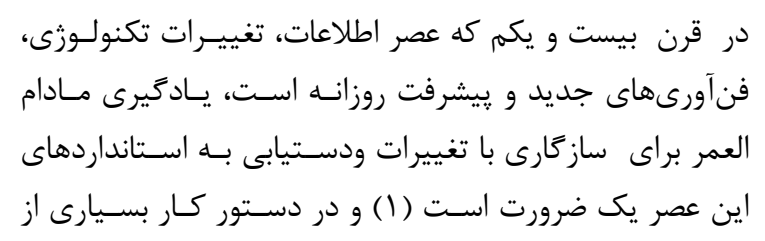

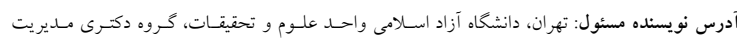
آموزشى، بِريوش جعفرى (email: pjaafari@yahoo.com) ORCID ID: 0000-0003-2916-8870 تاريخ دريافت مقاله: تV/9/V

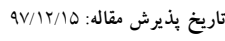


شد. نمونه كيرى در اين مطالعه هدفمنـد (Purposeful Sampling)

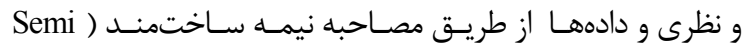
(structured يرستارى كه داراى مدرك دكتراى يرستارى بودند آغـاز و يـس از

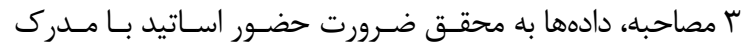

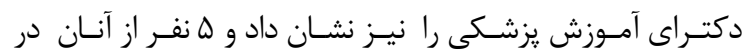

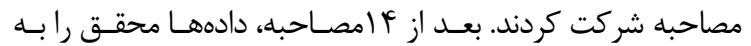
انجام مصاحبه با يرستارانى كه ضمن اشتغال بـهـ تحصـيل دردوره

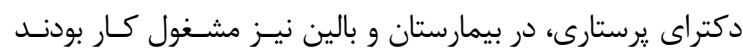

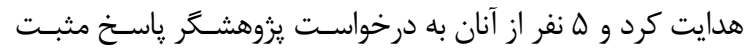
دادند. با ها نفر مصاحبه حضورى و با \& نفر از مشاركت كننـدكان به دليل مشغله كارى آنان، نداشتن وقت براى مصـاحبه حضـورى و و دورى راه، مصاحبه غير حضورى انجام شد. به طـورى كـهـ بــراى 1

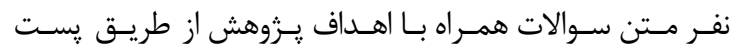

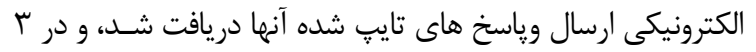
مورد اهداف و سوالات يزوهش از طريـق واتسـات ارسـال و ياسـخ

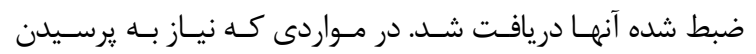

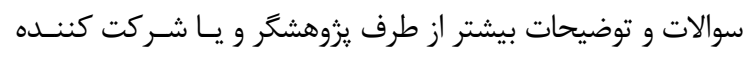

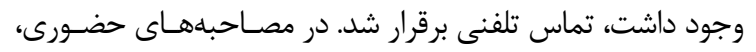

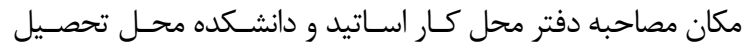

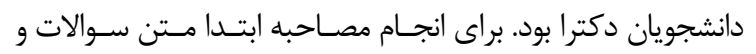
اهداف يزوهش همزمان با زرفتن وقت مصـاحبه و قبـلـ از ديـدار

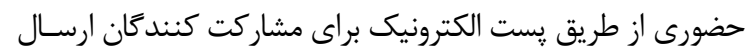

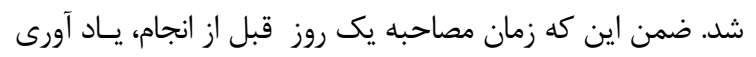

قبل از شروع هر مصاحبه در مورد محرمانه بودن اطلاعات و هويست

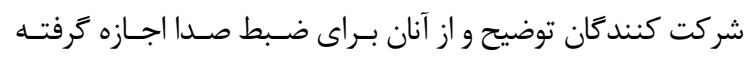
شد. زمان مصاحبه با توافق آنان تعيين شد. سوالهاى مصاحبه بـاز

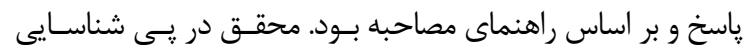

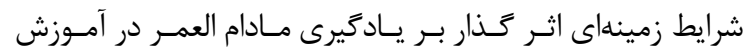

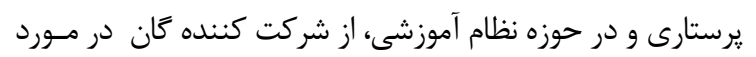

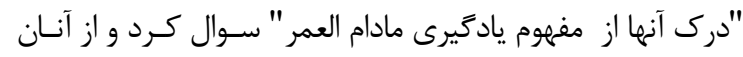

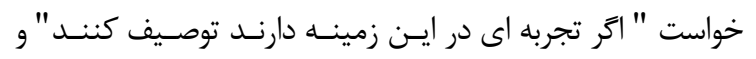

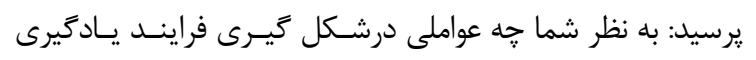

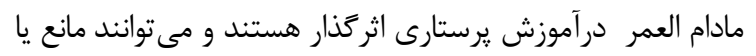
تسهيل كننده باشند؟ در حين مصاحبه، بر اساس پاسخ مشــاركت

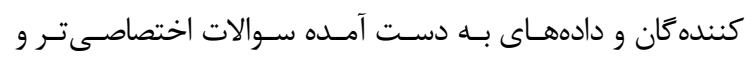

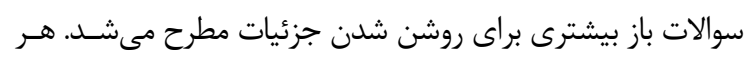

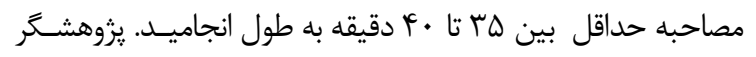

دانشجويان، نيازهـاى آنهـا را از لحـاظ يـادَّيرى درازمـــت در

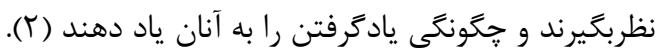

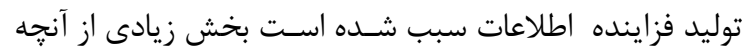
كه دانشجويان شاخه هاى مختلف علوم يزشكى در دانشكدهها

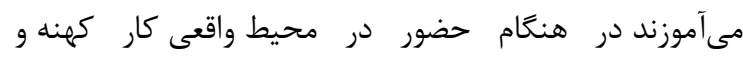
منسوخ شود. در جنين شرايطى به جاى انتقال مجموعهاى

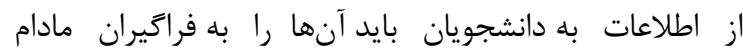

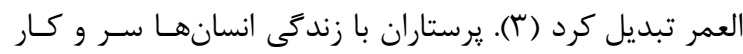

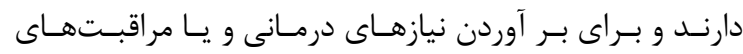

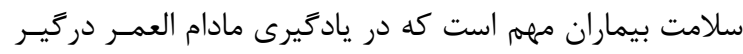

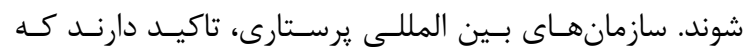

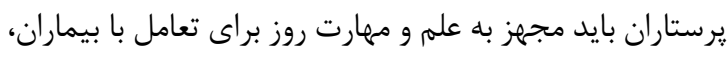

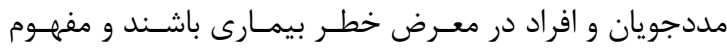

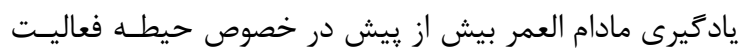

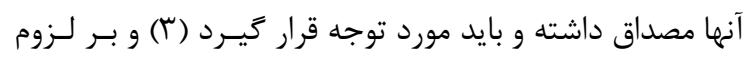

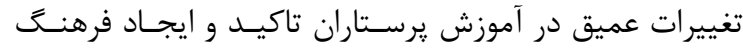

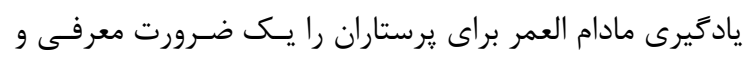

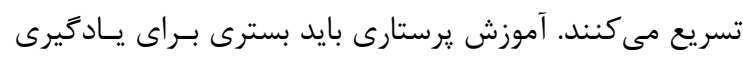

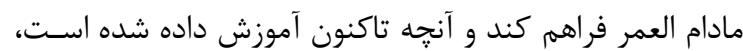

تغيير كند (ه-" ماد).

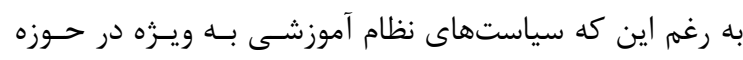

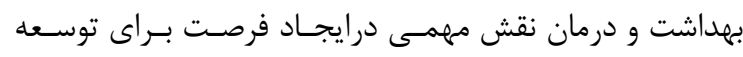

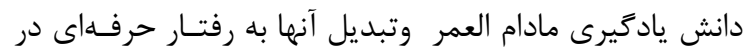

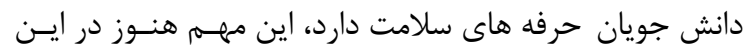

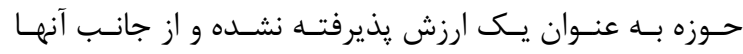

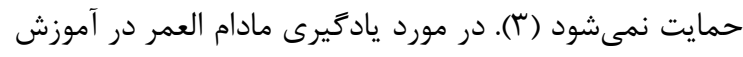

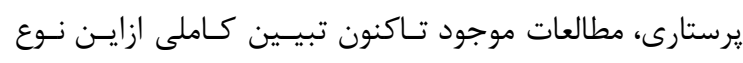
يادگيرى ارائه ندادهاند. توجه كافى به ديدكاه متخصصـان ايسن

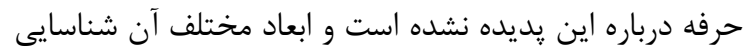
نشدهاند. لذا مساله يِيش روى يروهش حاض حاضر اين بود كه عوامل

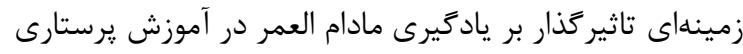

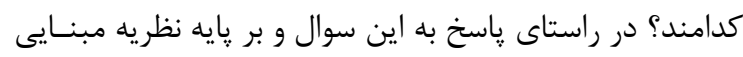

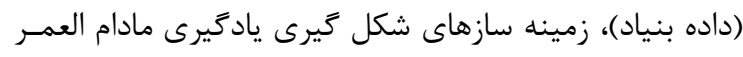
در حوزه نظام آموزشـى بـا نظرخـواهى از جمعسى از اسـاتيد و صاحب نظران حرفه يرستارى شناسايى شدند.

\section{مواد و روشهها}

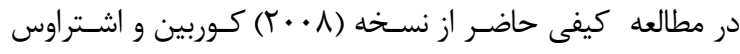
جهت جمع آورى و تحليـل دادههـا اسـتفاده (Corbin \& Strauss) 
(قابليت تعميم يافتههـا) در «ـرزوهش كمـى اسـت و نـام

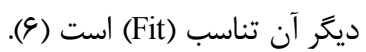

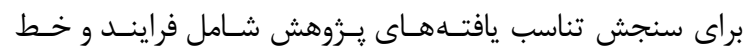

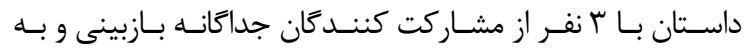

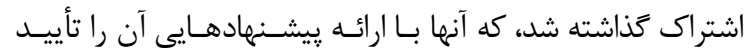

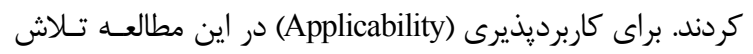

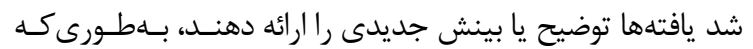

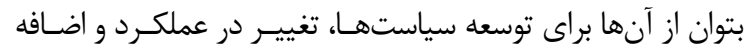

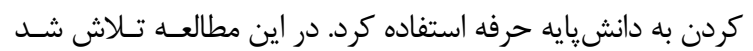
يافتهها در قالب مفاهيم و طبقات مناسب ارائه شود، بـهنحــوى كـهـ

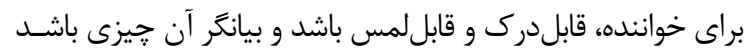
كه واقعاً دردادهها جريان داشته است.

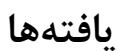

مشاركت كنند

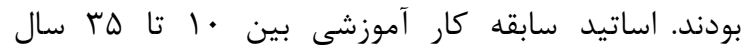

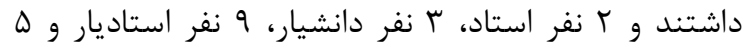
نفر دانشجوى دكترا بودند. با تحليل ديدگاه مشاركت

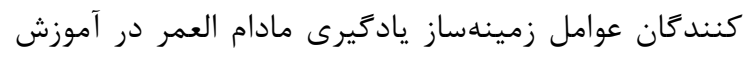

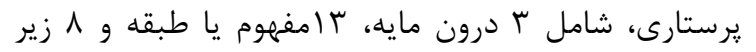

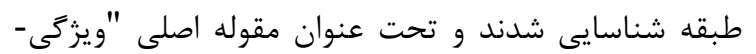
هاى نظام آموزشى" جاى گرفتند (جدول (1). الف- اولين درون مايه "سياست مذارىها" بود و و حاصل سه مفهوم به شرح ذيل بود: اباور و نگرش مديران

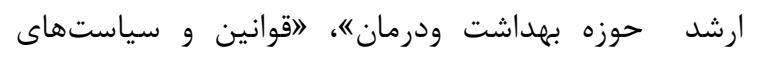

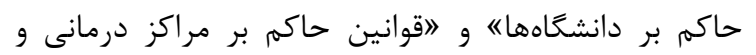

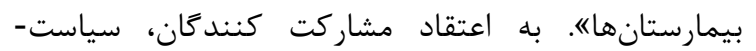
كذارىهاى موجود در جهت رويكرد يادگيرى مادام العمر بهر (مץ): معتقد بود: السياستها و باورهاى مديران، مسئولان

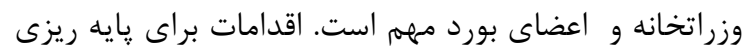

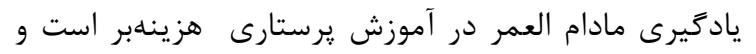
آنها بايد اعتقاد به لزوم يادگيرى مستمر در زيرستارى ييدا

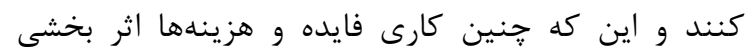
دارد در مورد آنجه قوانين و سياستهاى حاكم بر دانشگاهها طبقه بندى شد، مديريت حامى را زمينه سازى مهرم در شكل گيرى يادَيرى مادامالعمر در دانشكدههاى يرستارى

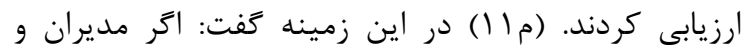

با مصاحبه با IV نفر به اشباع نظرى رسيد و براى اطمينان تـا 19 نفر انجام مصاحبهها ادامه يافت.

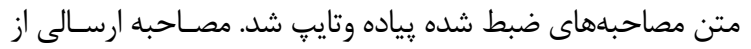

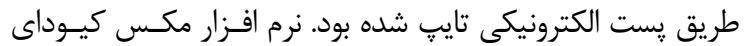

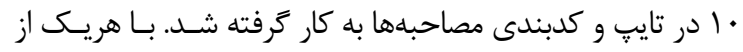
شركت كنند

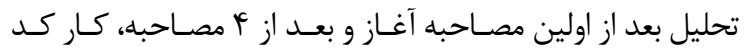
كذارى و دسته بندى انجام شد. در كدگذارى باز، متن هر مصاحبه

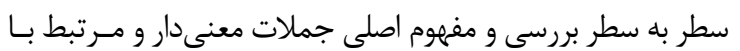

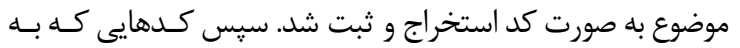

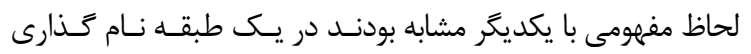

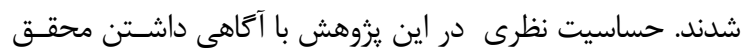

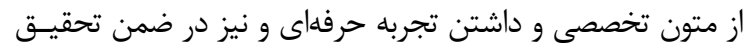

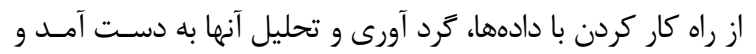

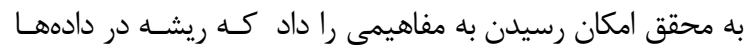

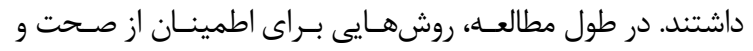
يايايى تحقيق مورد استفاده قرار گرفت.

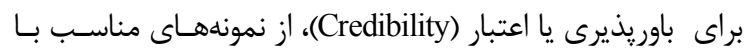

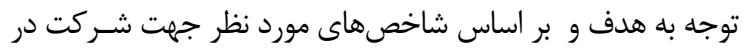

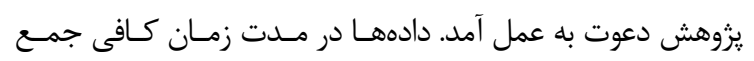

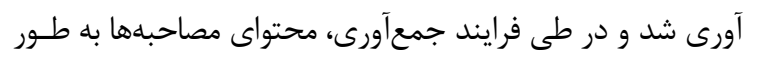

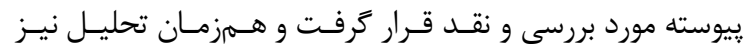

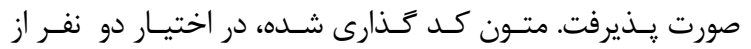
مشاركت كنندگان و دو نفر همكار كه با كار تحقيـق كيفـى آشــنا

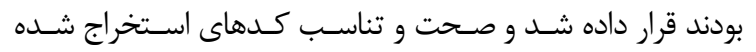
بازنخرى و در برخى موارد اصلاح شد.

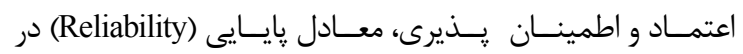
يزوهشهاى كمى است و به معنى پايدارى دادهها در طـول زمـان

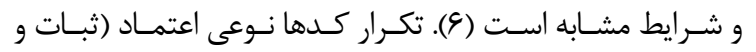

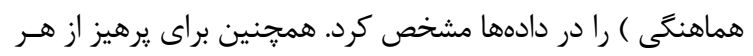
كونه عدم سوگيرى در تفسير دادههاى يزوهش از يكى همكـار كـهـ

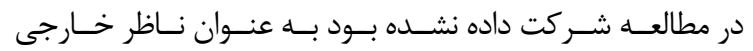
درخواست شد مراحل ززارش كار را بررسى كند.

براى نيل به قابليت تائيد يا تائيدٍـذيرى (conformability)، تمـام

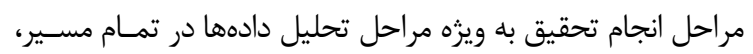

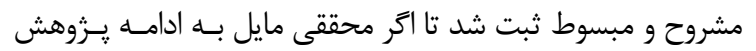

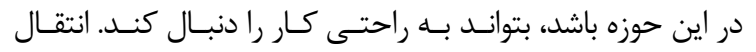
تيـذيرى در يـرزوهش كيفـى معـادل روايسى بيرونسى ( External 
معتقد بود: "يك برنامه درسى ينهان داريم كه هميشه غلبه

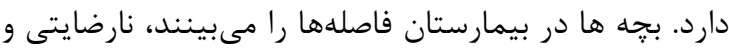
برخورد اجتماعى را مىبينند. اين ها همه كوريكولوم زينهان است و من به عنوان مدرس كه بر اساس كوريكولوم تدريس مى كنم، احساس مى كنم اين برنامه اجرا نمى شود"

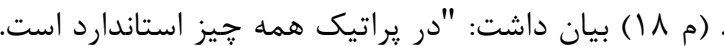

در بخش يك قيجى استريل ييدا نمىشد كه كرشان ران انجام دهند. اينها همه در انگيزه براى يادگيرى تاثير دارد.

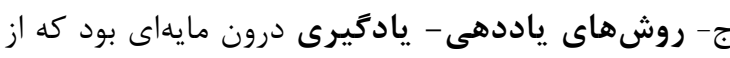

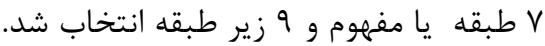
اولين مفهوم باور و مقاومت اساتيد بود. (م^)): بيان داشت: "براى ايجاد نگرش يادگيرى مادام العمر در دانشجو ابتدا

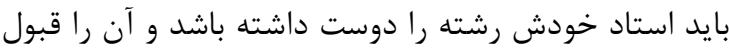
داشته باشد. به هر حال باور اساتيد وقتى ايفاى نقش مى كنند بايد براى دانشجو قابل استناد باشد. اين يك الزام

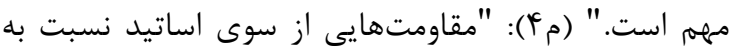

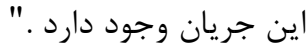

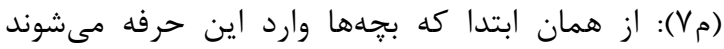
معلمين اين حرفه و به خصوص آنهان آنهايى كه اصنه مهارتهاى يرستارى را درس مى دهند، مسئول هستند كه بينش مناسب اين حرفه را القاء كنند.

نبود تدريس مبتنى بر ييوستخَى و كاربرد مطالب دومين مفهوم اين درون مايه بود. (مه): "تدريس بايد به گونهاى باشد كه دانشجو ارتباط

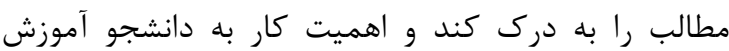

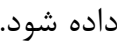
(ما (): "وقتى كه فردى جيزى را ياد مى گيرد علاقه به استفاده آن دارد و حس خوبى كه از به كار بردن مهارتش ئش در او به وجود مى آيد، انظيزهاى ميىشود براى ادامه دادن به به به به به

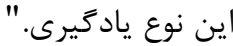

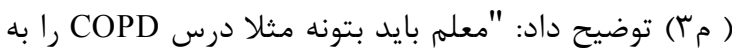

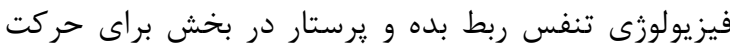

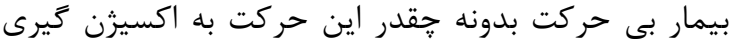

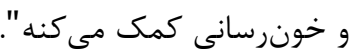
خلاء تدريس مساله محور / يثوهش محور مفهوم سوم

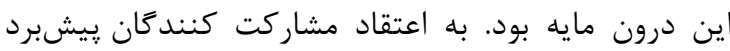
يادگيرى مادام العمر به يادگيرى حل مسئله وابسته است. (مه (1): در دانشجويان رشتههاى مختلف از جمله يرستارى مارى بايد در در جه اول توانايى شناخت و تفكر حل مسئله رشد بيدا كند. (مV): "اساتيد يرستارى بايد با طرح سوالات و
مسئولين دانشگاه اعتقاد به اين نوع آموزش داشته باشند، مىتوانند با تصويب قوانين و اشاعه دادن در معاونتهاى

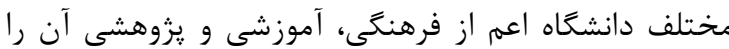
كسترش دهند. يايه ريزى يادگيرى مادام العمر بايد دغدغه

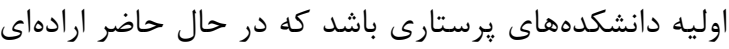

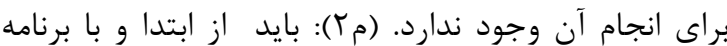
ريزى نگاه ما به سمتى باشد كه بخواهيم دانشجوى ما يادگيرى مادام العمر داشته باشد. قوانين حاكم بر مراكز درمانى و بيمارستانها مفهومى ماكى بود كه از ديد مشاركت كنندگان با سلب انگيزه از دانشجو و يا يرستار مانعى براى يادگيرى مادام العمر است. (می1): دست يرستار را براى اجرا باز بحذارند و از آنها مسئوليت

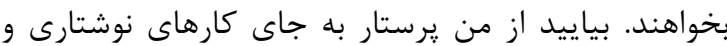

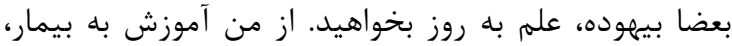

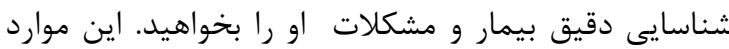
مرا به سمت يادگيرى دائم سوق خواهد داد. ب- برنامه درسى و سيستم ارزشيابى دومين درون مايه بود كه از مفاهيم "خلاء برنامه درسى و سيستم ارزشيابى

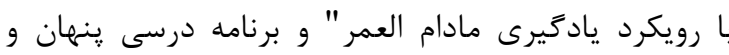
آشكار " حاصل شد. مشاركت كنندگًان معتقد بودند كه برنامه درسى

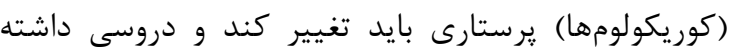

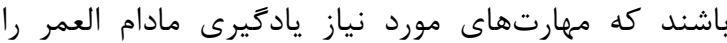

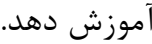
(مr): "برنامه درسى موجود دانشجو را در جهت ياد ميرى مادام العمر راهنمايى نمى كند". به اعتقاد آنان رويكرد ياد كيرى مادام العمر در آزمونها و ارزشيابى هم بايد لحاظ

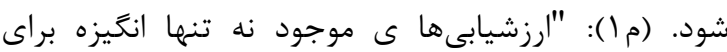
يادگيرى ايجاد نمى كند، بلكه با ناديده گرفتن توانايىهاى فردى دانشجو مانعى در جهت يادگيرى است. (م ؟) معتقد است: بايد تفاوت بين دانشجوى داراى تفكر انتقادى و

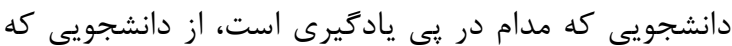
به هر حال جلو ميره در ارزشيابىها ديده شود. (م 1) بيان داشت: "اگر تفاوتها ديده نشود اثر منفى خواهد داشت. با سابقهتر از ما علمشان به روز نيست كار مي كنند، سيستم داره باهاشون همراهى مى كنه. من يادبخيرم كى

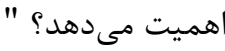
از ديد مشاركت كنندگان ناهمخوانى بين آنجه دانشجويان يرستارى در كلاس آموختهاند با آنجه كه در محيط بالينى تجربه مى كنند، از موانع يادگيرى مادام العمراست. (مV): 


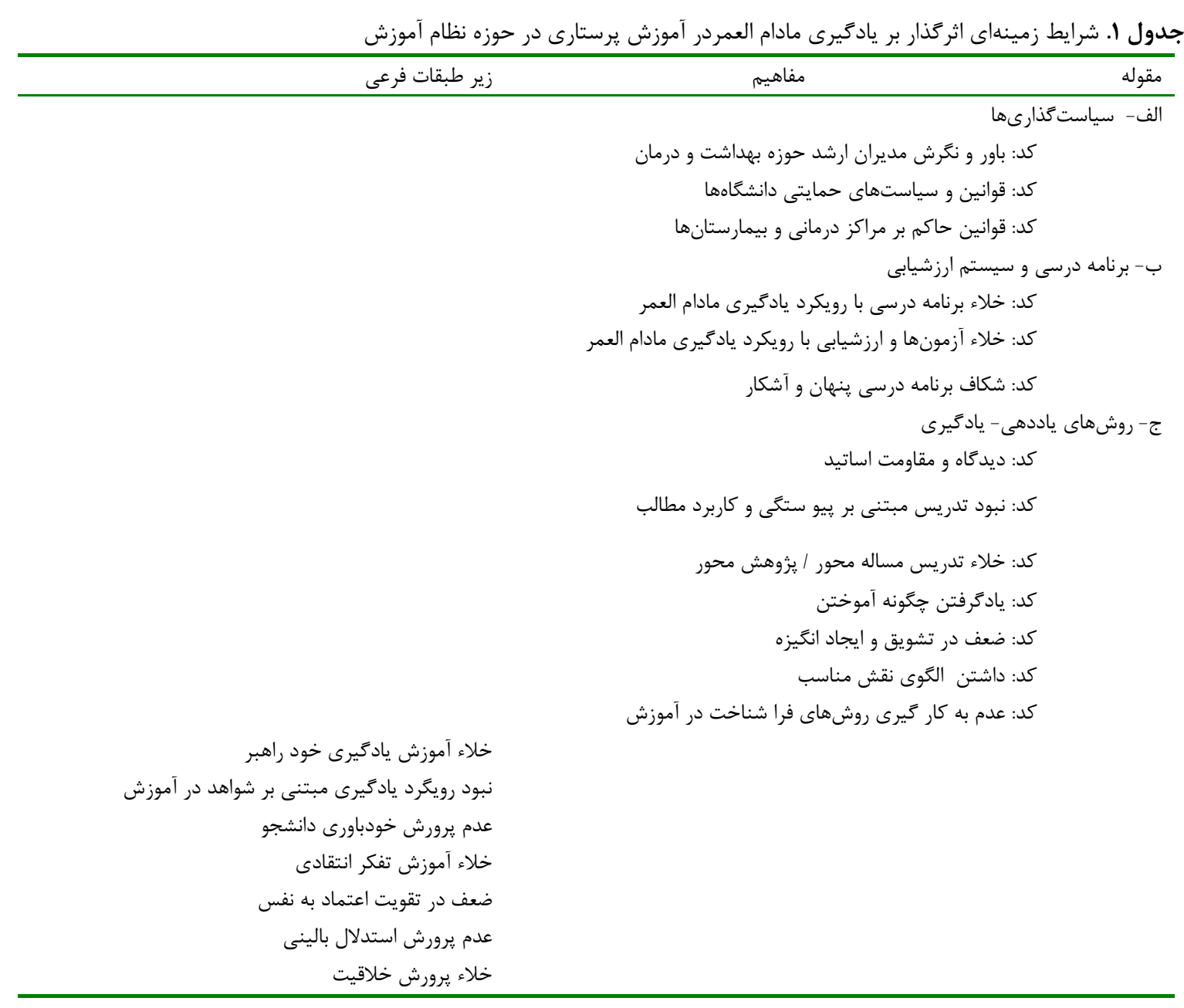

مفهوم ينجمى كه از تجربه مشاركت كنندگًان دريافت شد، ضرورت توجه به دانشجو و ايجاد انخيزه براى استمرار يادگيرى است. (م Y I (): تاثير تشويق بلند مدت است است و برعكس آن ناديده

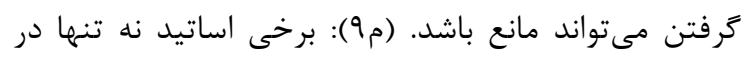

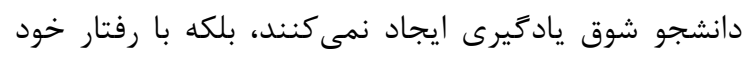

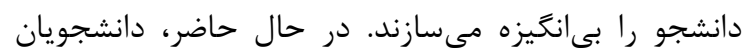
انغيزه لازم براى يادگيرى به دلايل متعدد ندارند. داشتن الكوى نقش مناسب از ديد مشاركت كنند

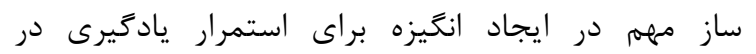

$$
\text { دانشجوى :برستارى ارزيابى شد. }
$$

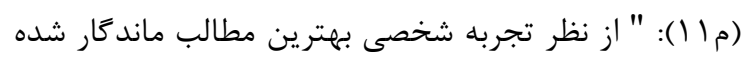

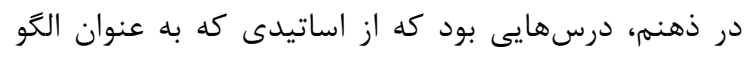

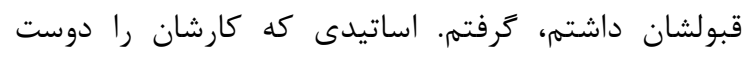
داشتند، ييشرفت داشتند و ارتباطى بين دانشجو و استاد

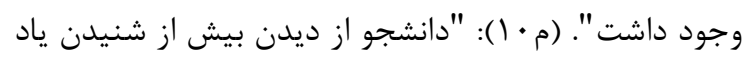

سناريوهاى هوشمندانه، ذهن دانشجو را عادت دهند به

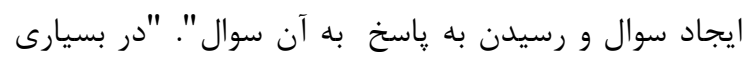

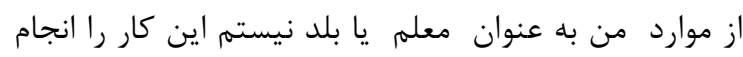

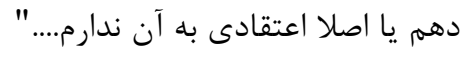

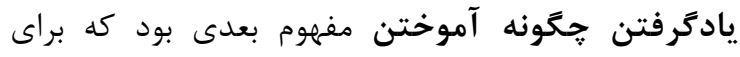
استمرار يادكيرى ضرورى شناسايى شد. در تجربه مشاركت كنندگان، با توجه به تغيير سريع دستاوردهاى علمى درى درى

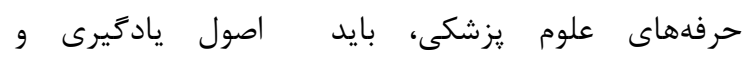
توانمندىهاى مورد نياز آن آموخته شود.

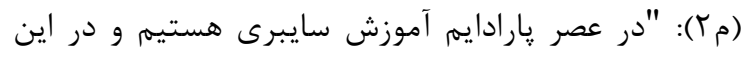

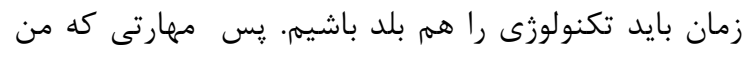

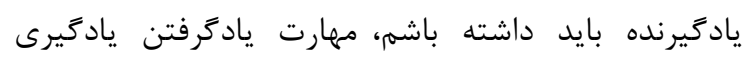
است. من فراگير نياز به مهارتهاى فراشناختى و دانستن اينكه جه جيزى را جطور بايد ياد بخيرم دارم". 
دانشجو مى گيريم، به خصوص در ترم يك يرستارى، و

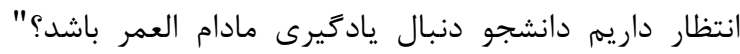

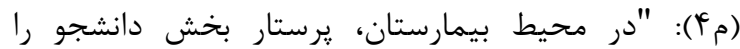
سركوب ميكنه، يك تيكه از اعتمادش كنده ميشه و وقتى يزشك از اتاق بيرونش ميكنه يك تيكه ديگه ازش كنده

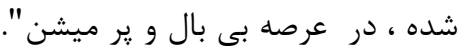

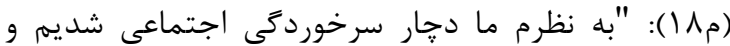
خودمان را باور نداريم. من به دانشجوى عرصه ترم آخر، كار

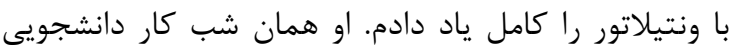
داشت. صبح تعريف كرد كه بيمار بدحال داشته و كسى بلد

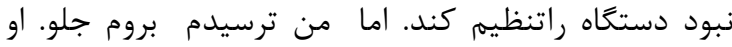
با وجود اين كه آموزش كرفته و علمش تازه به روز شده بود بود اما در محيط كه قرار گرفت جو محيط به او جسارت و جرات عمل را نداد. شايد اتتظار نداشت كسى كه ييش از او بوده بلد نباشد. لذا به آموختههاى خودش شك كرد". به ريه نظر مىرسد دانشجويان و يرستاران نياز به شناخت و اعتماد به توانايىهاى خود دارند. (ما): "دانشجو براى ارائه مراقبت مناسب از مددجو هم هم بايد فكر كند و هم هر لحظه از دانستههايش استفاده كند. هم آن دانشى كه از قبل مىدونسته يا دانشى كه طى يك

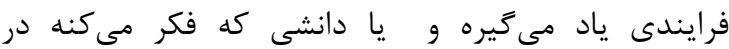
موردش ضعف داره و بايد بره در آن خودش را قوىتر بكنه. لازم است از ابتدا شرايطى براى دانشجوى يرستارى فراهم

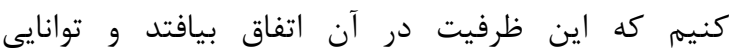
شناسايى، درك و به كارگيرى اطلاعات را ريدا كنه." () () خلاقيت عامل روانشناختى ضرورى براى يادگيرنده مادام العمر شدن است. دانشجو بايد به سمتى هدايت شود كه خود خلاق شود و بتواند در موقعيتهاى متفاوت و با توجه به شرايط، يك كار مشخص را انجام دهد.

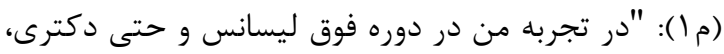

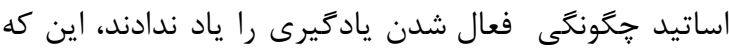
קطور مطلب در بياوريم، اعتبار ان را كنترل و ارائه دهيم.

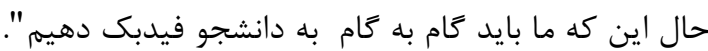
(م1) (): "سيستم آموزشى ما براى جستجو ضعيف است. من آن

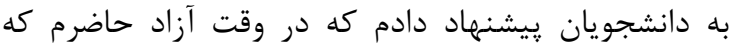
جستجوى سيستماتيك را ياد بدهم، اما ياد ندارم كه در

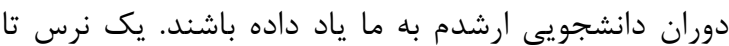
وقتى به تحصيلات تكميلى دست ريدا نكرده باشه، هنوز

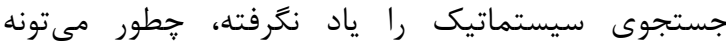
يادگيرنده مادام العمر بشه و جطور علمش را به روز روز بكنه".
مى گيرد و اگر الكوهاى خوبى در هر محيطى داشته باشد، جه مربى خودش يا يرستار بخش بهتر ياد خواهد گرفت.

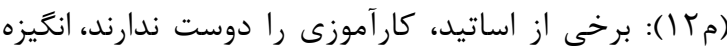
براى كار با دانشجو ندارند و ترجيح مىدهند كار يزوهشى انجام بدهند، و دانشجو متوجه ميشه كه حرف استاد جقدر واقعى است. خلاء روشهاى فراشناخت به عنوان آخرين طبقه اين درون مايه، از تحليل جزير طبقه شامل خلاء يادگيرى خود راهبر، نبود يادگيرى مبتنى بر شواهد، عدم ڤيرورش خود باورى، خلاء آموزش تفكر انتقادى، ضعف در تقويت اعتماد به نفس، استدلال بالينى و خلاقيت، يادگيرى فعال، و خلاء آموزش مهارتهاى سواد اطلاعاتى به دست آمد. از ديد بـ ديد مشاركت كنندگان، ضعف دانشجويان در اين مهارتها از موانع مهلم در استمرار يادگيرى است.

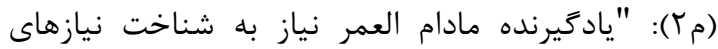

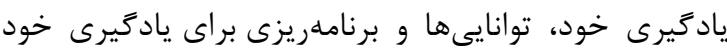
دارد و اينها يعنى مهارتهاى خودراهبر كه دانشجويان در

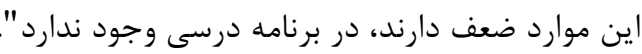

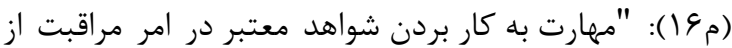
ضروريات مراقبت در دنياى امروز و نيازهاى يادگيرى مادام

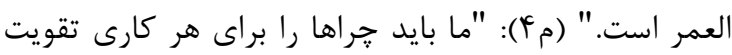

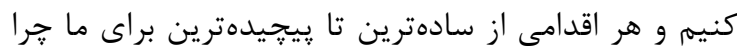
ايجاد كند. جراها عاملى مىشود كه فرد برود دنبال مسئله و رويش فكر كند و تحقيق كند". (م1) (1): "وقتى من با شواهد و مبتنى بر تحقيق بروم جلو و خودم را نشان دهم و بازخورد دريافت كنهم، اينها در من

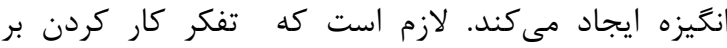
اساس شواهد در مراقبت رواج ييدا كند كه من يرستار

محركى براى اضافه كردن به آموختههام داشته باشم". (م1)(1): تفكر انتقادى مهارتى ضرورى براى تصميم گيرى بالينى است و به دانشجو كمك مى كند مستقل فكر كند، راهكار بدهد و صرفا اجرا كننده فرامين نباشد. ما تفكر نقاد را با روتين مدارى در ڤيرستارى كشتهايه. در دانشگاه

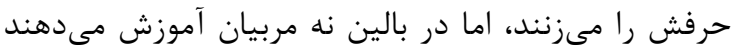
و نه در بالين به اين كار بهاء داده ميىشود. تقويت اين مهارت بالينى ضرورى و عامل انخيزشى است.

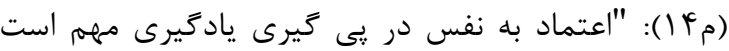
كه در اغلب دانشجويان به دلايل متعدد از جمله رفتار ما اساتيد و يا جالشهاى محيط بالين در طول تحصيل كم

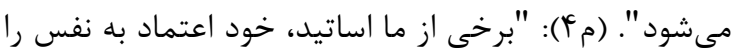


يرستارى باشد كه در حال حاضر ارادهاى براى انجام آن وجود مادينه

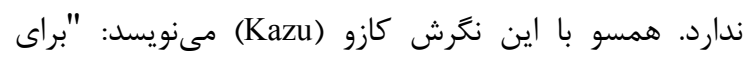

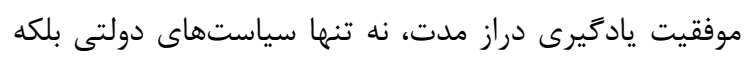

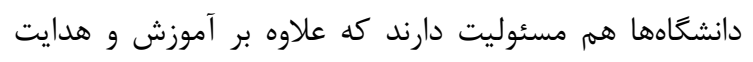

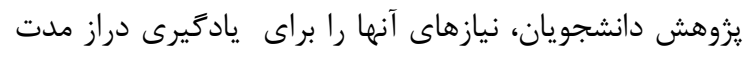

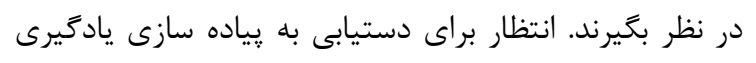

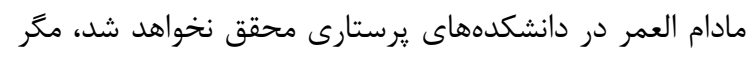

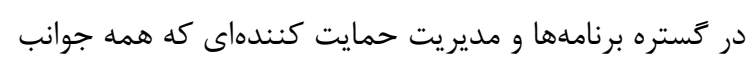
و زمينههاى حركت به سمت اين هدف را را مورد بررسى قرار

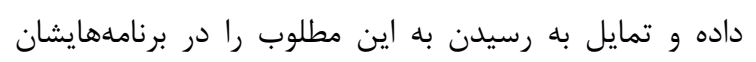

داشته باشند (r).

به علاوه، تحليل مصاحبهها نشان داد قوانين بيمارستانها و و دانئ.

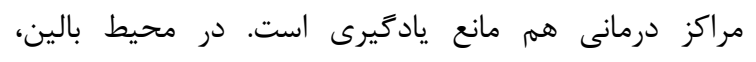

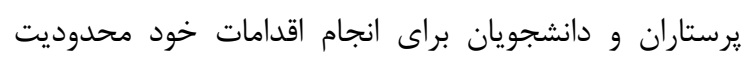

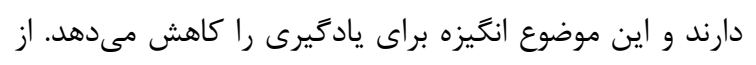

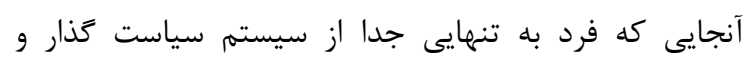

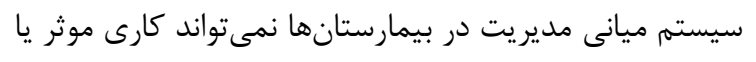

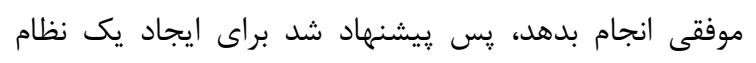

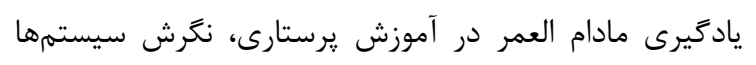
هم بايد تغيير كند. در يزوهشهاى متعددى قوانين دست ويا گير در بيمارستان،

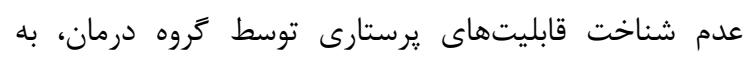

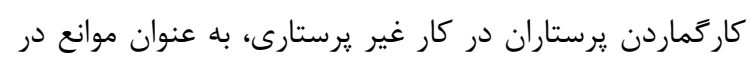

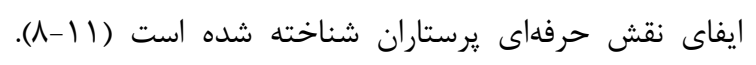

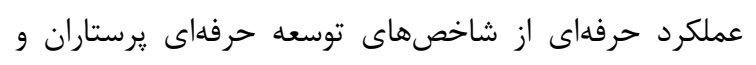

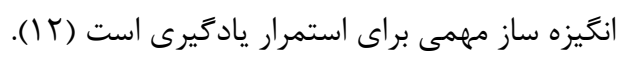

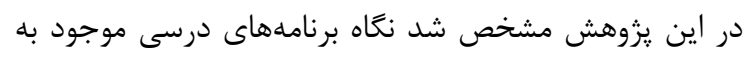

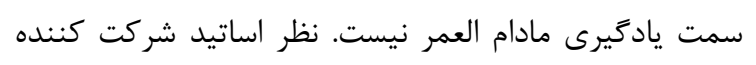

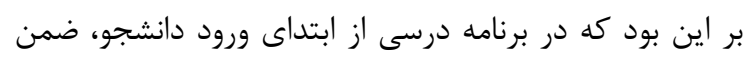

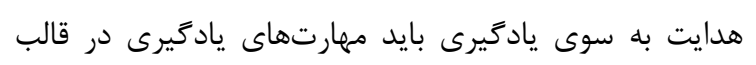

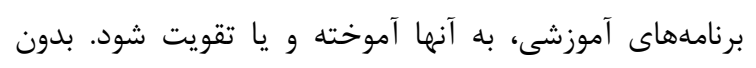

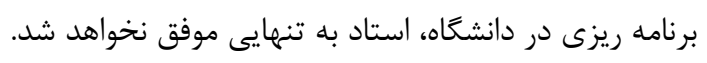

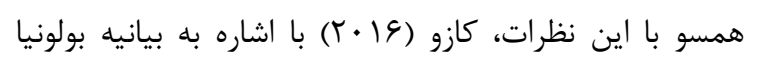

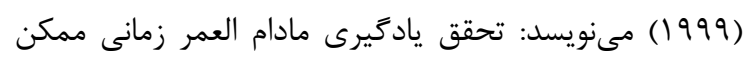

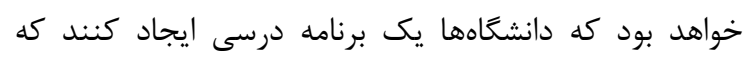

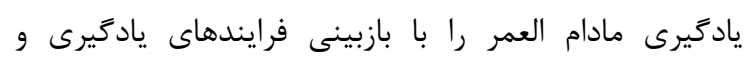

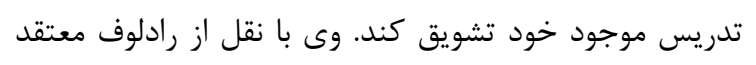

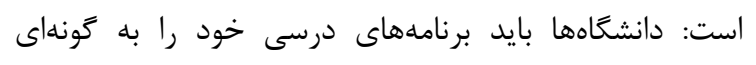

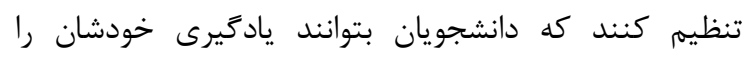

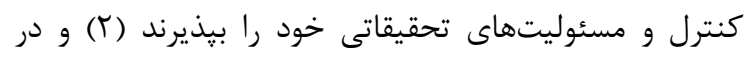

وابستخى مفهوم يادگيرى مادام العمر به زمينهها و تاثير

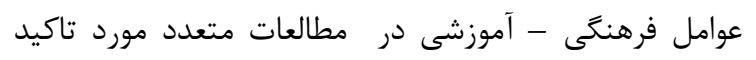

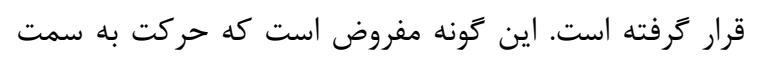

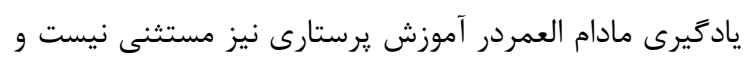

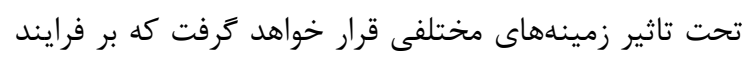

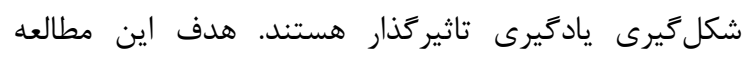

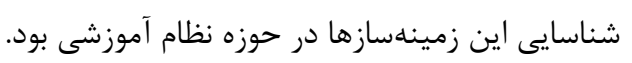

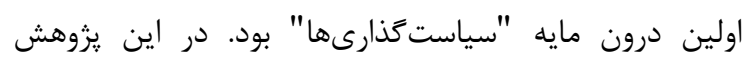

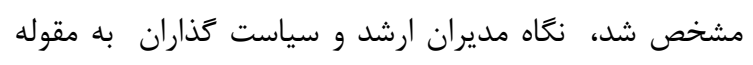

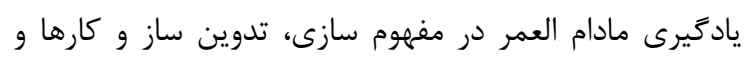

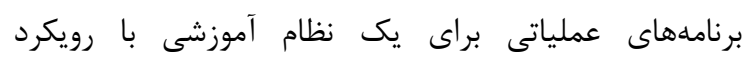

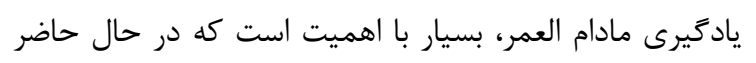

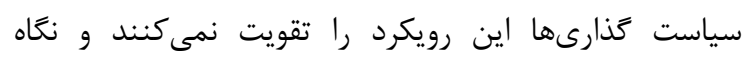

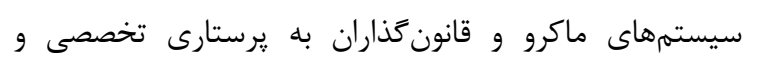

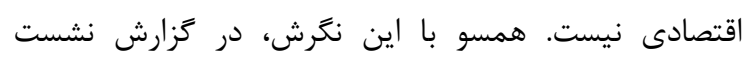

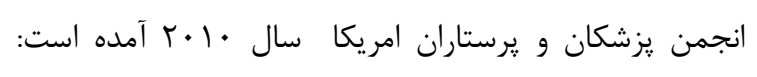

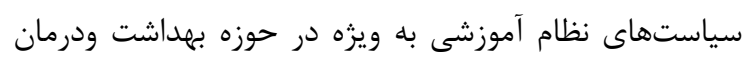

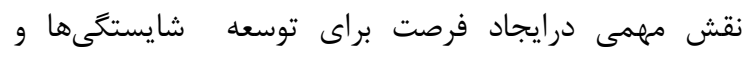

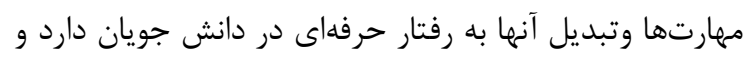

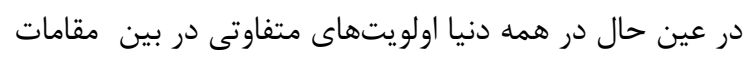

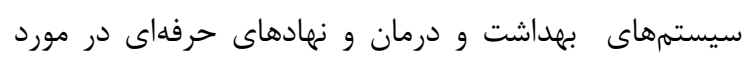

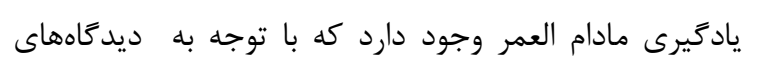

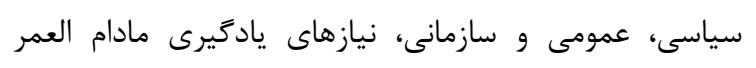

متخصصان مراقبتهاى سلامت را تحت تاثير قرار مى دهى دهد.

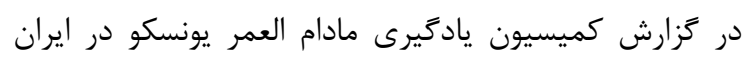

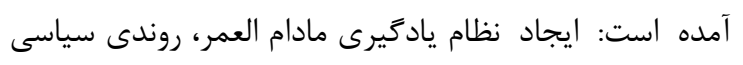

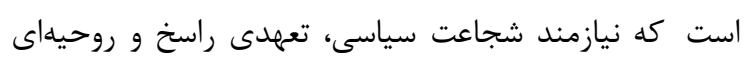

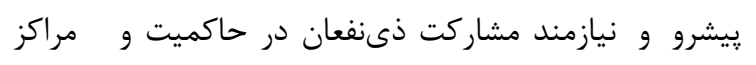
تصميم گيرى است و لازم است هماهنكى در سياست كذارى،

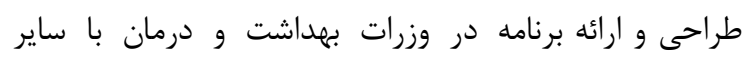

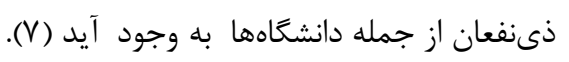

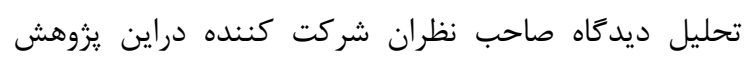

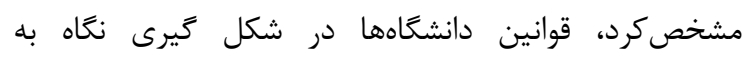

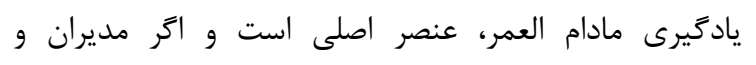

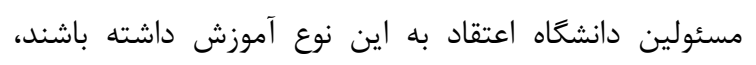

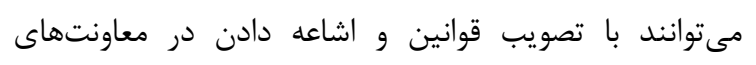

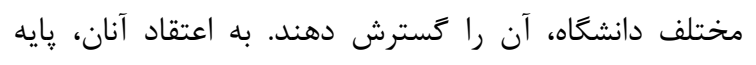

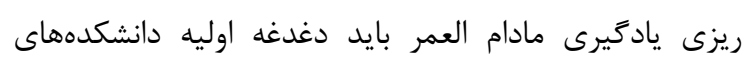


نقل از جكوس (1999) اضافه مى كنند: بسيارى از اساتيد در

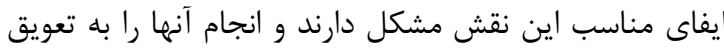

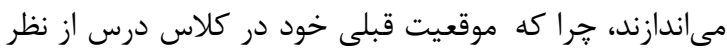
حاكميت، خبركى، متكلم وحده بودن و حتى سخنران درجه

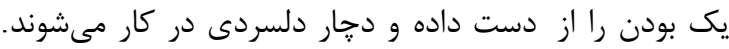

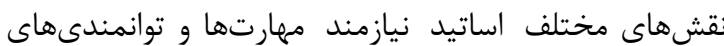
مختلفى است و لازم است اين نقش توسط آنان شناخته شده و

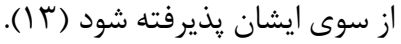
نكَرش دانشجويان به ضرورت يادكيرى، مسئوليت اجتماعى و مشاركت در جامعه، همان نكرشى است كه در روند آموزشى و

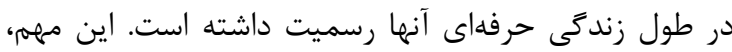

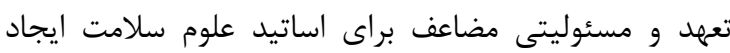

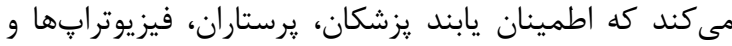

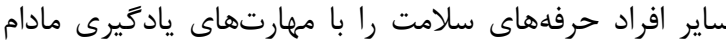

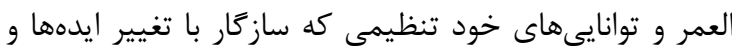

محيطها باشد، يرورش مى دهند (T (I).

تدريس مبتنى بر يِيوستگى و كاربرد مطالب در اين مطالعه براى استمرار يادكيرى مههم ارزيابى شد. مطالعات متعددى نيز بر لزوم تسلط استاد بر روشهاى موثر آموزشى، برقرارى ارتباط ميان مباحث نظرى و كاربرد آنها و ير كردن شكاف ميان مطالب نظرى و عمل را با توضيح به دانشجويان، تاكيد دارند.

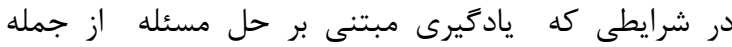
قابليتهاى مورد نياز يادكيرى مادالعمر اعلام شده است (بآ)،

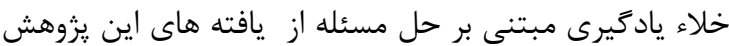
بود. هدف عمده در روش حل مسئله يرورش اذهانى إنى إنعطاف

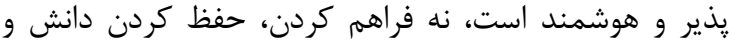
كسب راه حلهاى آماده. براى نيل به اهداف يادكيرى مادام

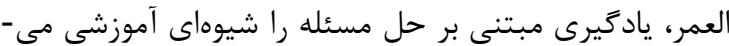

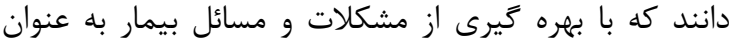

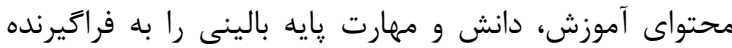

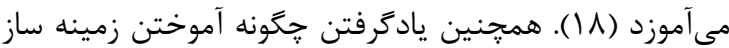

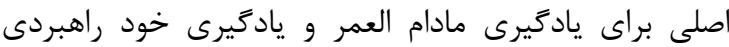
شناسايى شده است. يكى از راهكارهايى كه مى تواند يادگيرى

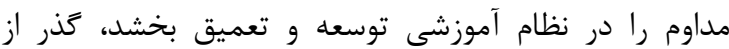
"ياددهى" به "ايادكيرى" است و مستلزم آن است كه فرد

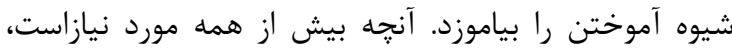

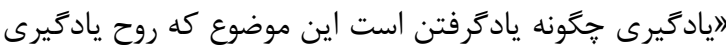

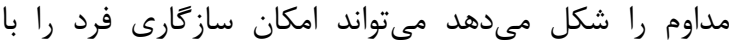
دكر گونى هاى سريع آينده ممكن سازد (1) (1).
سراسر زندگى حرفهاى خود حفظ و گسترش دهند. يكى از راههاى دستيابى به اين اهداف ادغام مهارتهاى يادئ دادكيرى

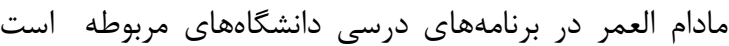

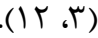

يافتهاى يزوهش همجنين نشان داد، ارزشيابىهاى موجود نيز نه تنها انكيزه براى يادكيرى ايجاد نمى كند، بلكه با ناديده كرفتن توانيىهاى فردى دانشجو مانعى در جهت يادئيرى إديرى

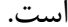

منابع متعددى اين يافته را تاييد مىكند (••-1). جنبههاى ارزيابى آموزش و بازخورد، كليد حمايت از توسعه مهارتهاى إنى

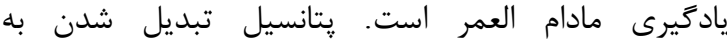
يادكيرندكان خودتنظيم و فعال، به كيفيت بازخورهاى داخلى و خارجى آنها مربوط است (YI). آزمونها در آموزش علوم

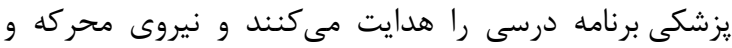
برانكَيزنده دانشجويان براى يادَّيرى هستند و در در عين حال

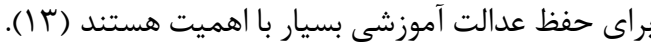
در اين يزوهش، كوريكولوم ينهان يعنى ناهمخوانى بين آنجه

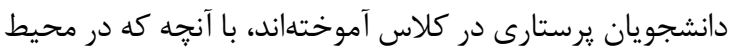
بالينى تجربه مى كنند، از موانع يادگيرى مادام العمر شناسايى دايى داسي شد. در منابع متعددى همسويى با اين ديدكاه وجود دارد (1)،

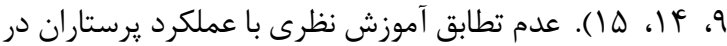
بالين منجر به بلا استفاده ماندن اندوختههاى علمى آنان و تبعيت از روشهاى سنتى معمول در بالين مىشود كه اين امر

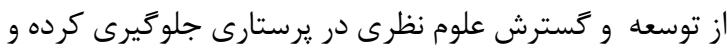
به افت كيفيت در ارايه خدمات يرستارى مىانجامد و در در عين حال باعث مىشود دانشجو در محيط كار با تعارضاتى بين

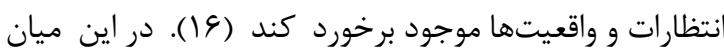
فرايند ياددهى- يادكيرى و ارزشيابى نيز داراى ساختار مشخصى نيست كه نياز به تغيير كوريكولوم را دو جندان

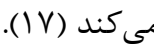
در رابطه با نكَرش و مقاومت اساتيد، يافتهها نشان داد برخى اساتيد دنبال نكرش يادكيرى مادام العمر نيستند و تمايلى به يادكيرى آن ندارند و به نوعى مانع از تغيير سيستم سنتى نانى هستند. شايد به اين دليل كه خود تجربهاش نكردهاند و تغيير

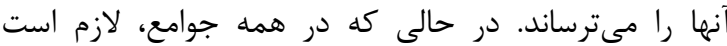
معلمها بيشتر از ساير افراد جامعه فراگير مادام العمر باشند. در دراند اين رابطه، يزدانى و همكارانش مىنويسند: حركت به سمت دانشجو محورى نيازمند يك شيفت اساسى در نقش استاد است

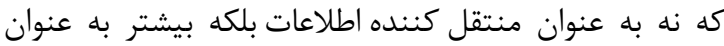

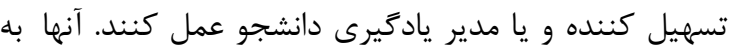


مى مهند. خالش اساتيد، شناخت كسانى است كه كمتر توانا

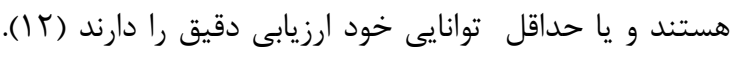

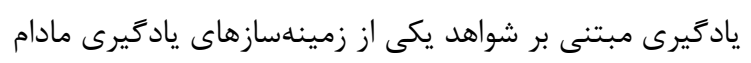

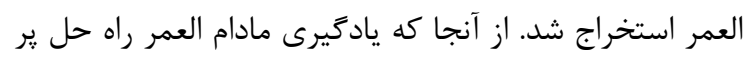

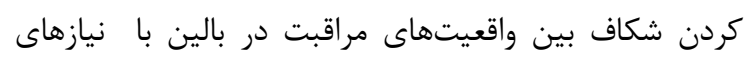

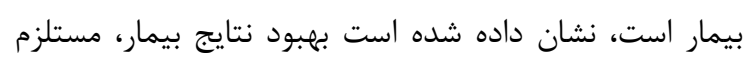

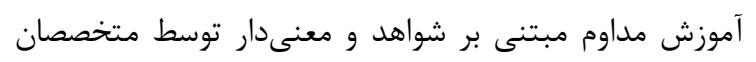

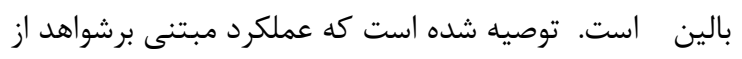

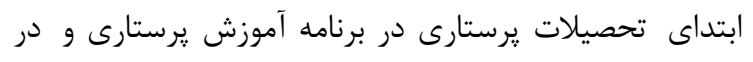

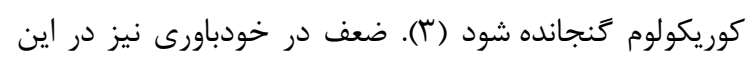

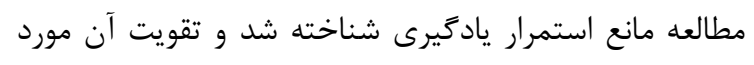

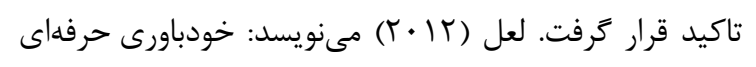
نقش مهمى در تحقق رسالت نظام سلامت و افزايش ميزان

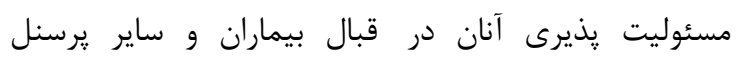

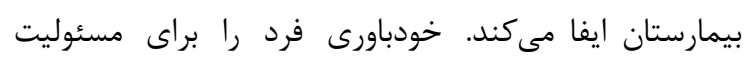

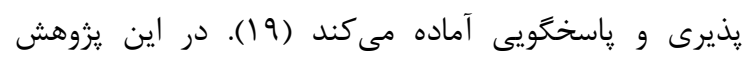

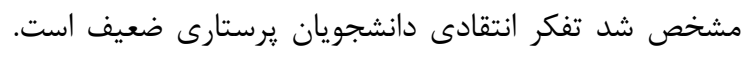

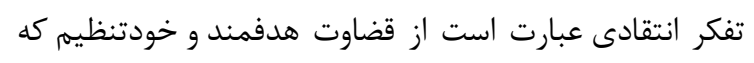

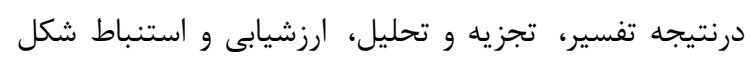

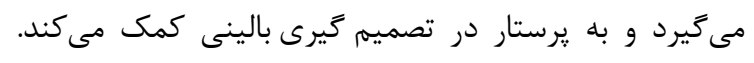

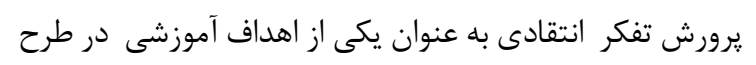

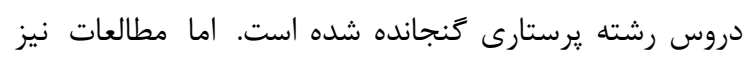

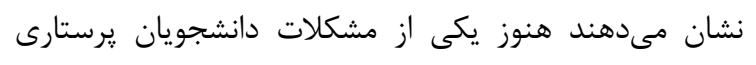

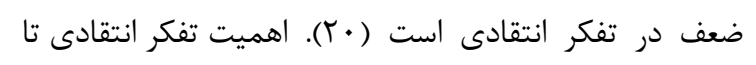

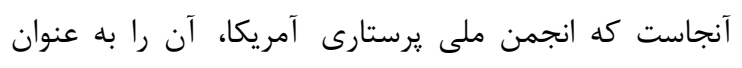

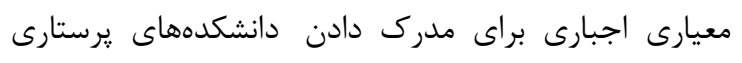

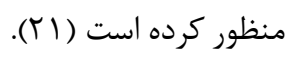

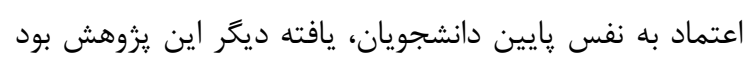

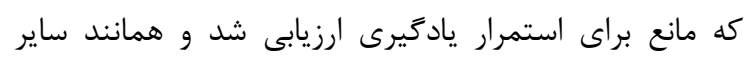

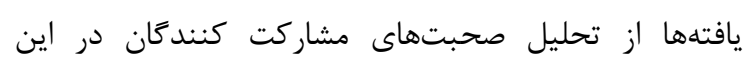

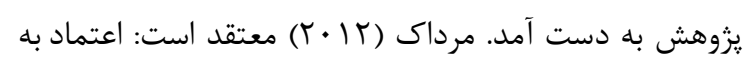

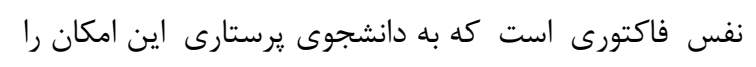

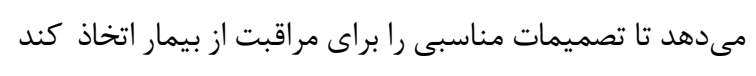

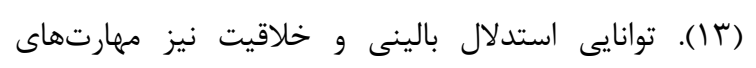

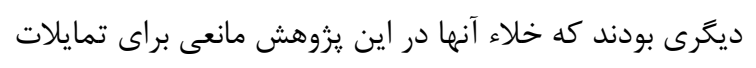

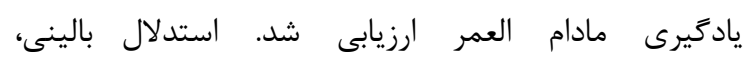

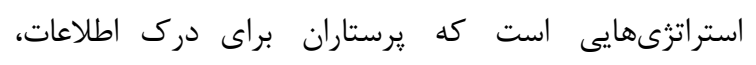
شناسايى و تشخيص مشكلات بيماران از آن استفاده مى كنند. نوعى تفكر بالينى كه اساس آن شناسايى نكات كليدى است.

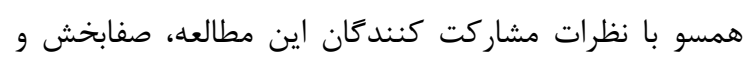

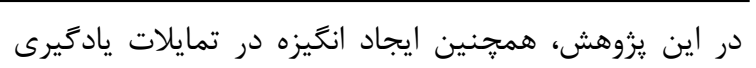

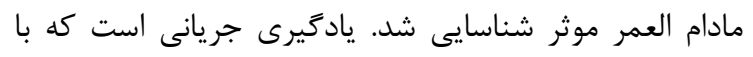

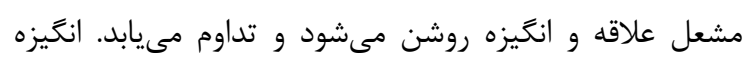

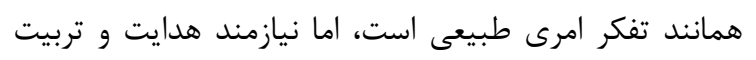

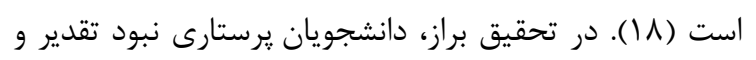

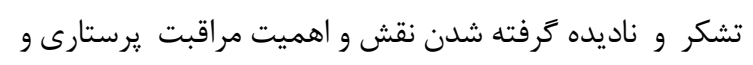

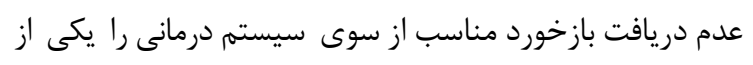

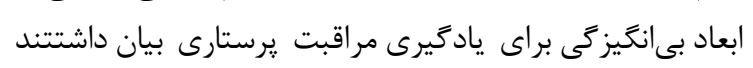

در اين يُروهش همجنين، داشتن الكوى نقش هم مانع و هم تسهيل كننده يادكيرى ارزيابى شد.

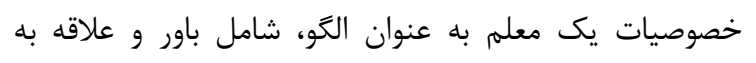

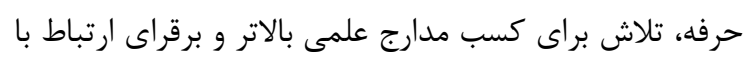

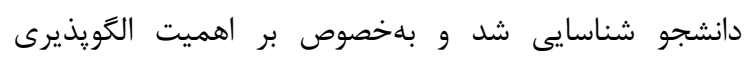

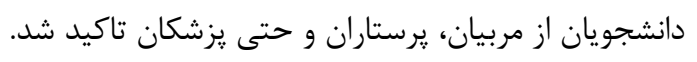
يزدانى و همكارانش مىنويسند: الكوكيرى از استاد احتمالاًا

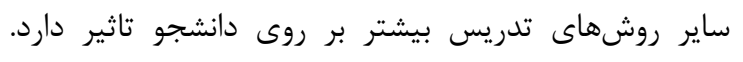

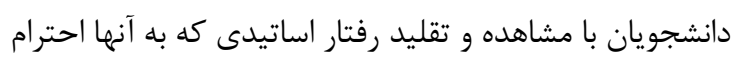

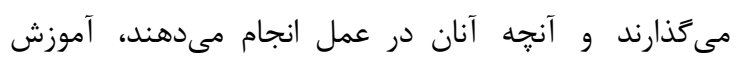

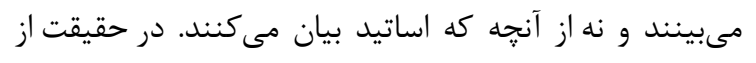

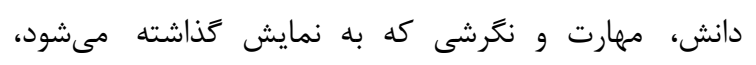
مى آموزند (1) (1).

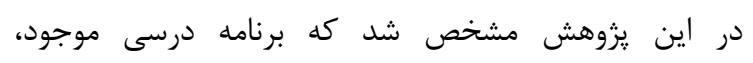

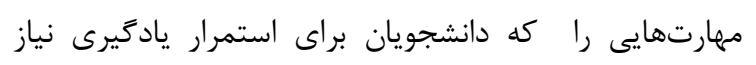

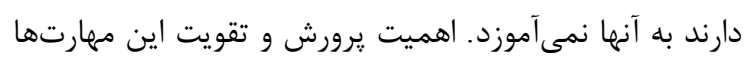

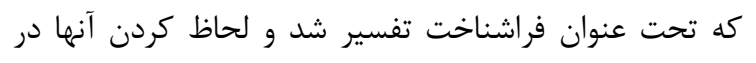
برنامه درسى، در تحقيقات مربوط به اين حوزه مورد تاكيد قرار

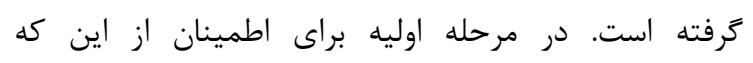

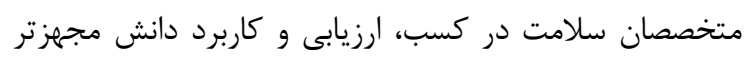

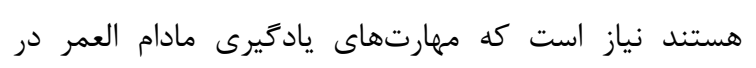
برنامههاى درسى دانشخاههاى حرفه سلامت ادغام شوند (بار).

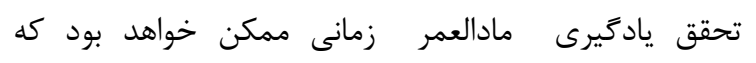
دانشكاهها يك برنامه درسى ايجاد كنند كه يادئ يادكيرى مادام

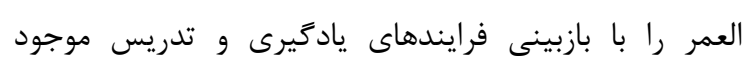

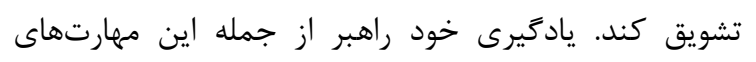

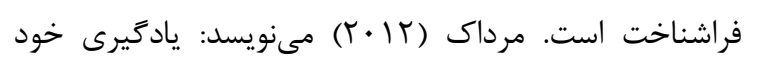

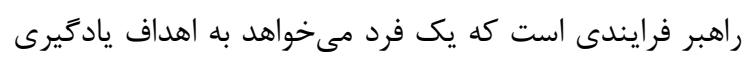

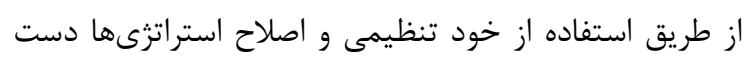

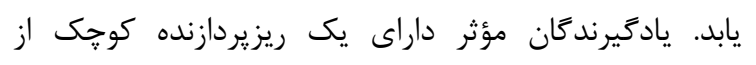

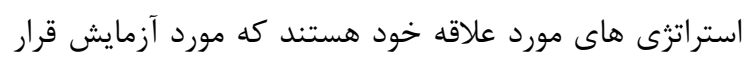


اجرايى شدن آن كمك مى كند. ايجاد فرهنَ يادَيرى مادام العمر در آموزش يرستارى كه جزو نظام آموزش عالى كشئ كشور

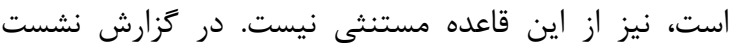
يونسكو در تهران نيز آمده است، ايجاد نظام يادگيرى مادام

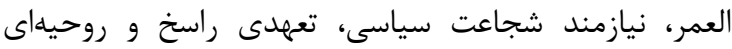
ييشرو است (V). براى يادگيرى مادامالعمرهاى جوامع بايد فرصتهاى جديدى را براى افراد خود تدبير كنند و اين امر به به به

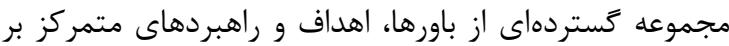

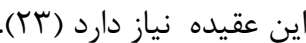

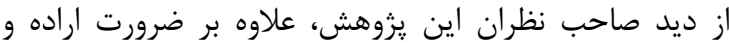

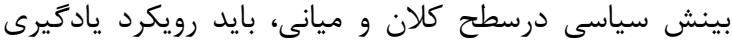

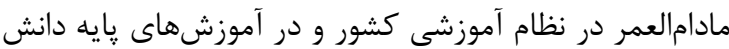
آموزان كنجانده شود تا به واسطه آن فرهنگ يادَّيرى مادام العمر ايجاد شود. در رابطه با آموزش يرستارى نيز، اين

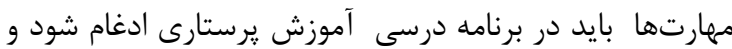

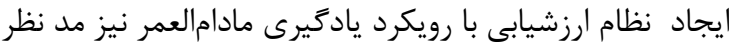
قرار كيرد. منابع نيز بر اين راهبرد تاكيد دارند: براى اطمينان از اين كه متخصصان سلامت در كسب، ارزيابى و كاربرد دانش مجهزتر

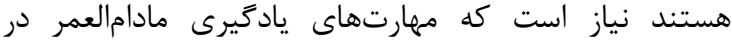

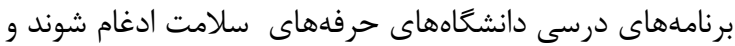
طراحان و برنامهريزان درسى، اعضاى هيئت علمى و ديكران بايد آن دسته از برنامههاى درسى را ترسيه، تدوين و توسعه دهند كه بر ارزشهاى يادكيرى مادامالعمر تأكيد داشته باشد

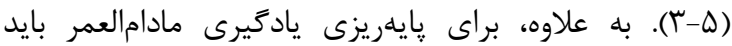

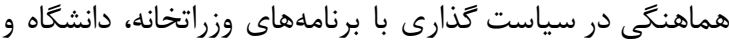

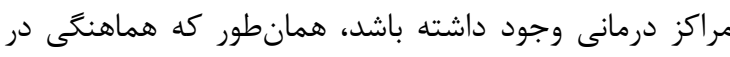
آموزشها، از ابتدايى تا دانشخاه، بايد باشد. براى تحقق يادكيرى مادامالعمر بايد محيطهاى دانشخاه و

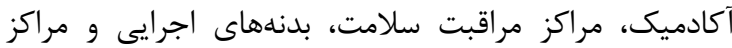
اعطاى مدرى و صلاحيت حرفهاى، برُدهاى تخصصى و ساير مراكز مربوط به سيستمهاى درمان، با هم همكارى و تشريك

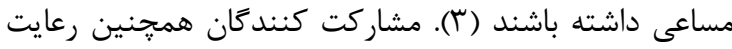
الزاماتى در كل سيستمهاى ماكرو، ميكرو و مزو را براى اجر ايى هايى شدن راهبردهاى پيشنهادى ضرورى دانستند. منابع نيز مىنويسند: واحدهاى اعتباربخشى بايد صريحا به تدورين استانداردها و ملاحظات مورد انتظار در مورد برنامههايى كه بدائ مهارتهاى يادكيرى مادامالعمر را ارتقاء داده و ارزيابى مى كند بيردازند. محيطها و سيستمهاى بهداشت و درمان، كارفرمايان و سيستمهاى اعتباربخشى آنها بايد از ارزش يادكيرى مادام

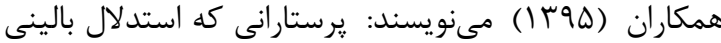
ضعيف دارند در شناخت بيمار، تشخيص شرايط بيمار و نجات

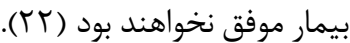
كسترش خلاقيت را بايد يكى ديكر از بنيانهاى يادكيرى

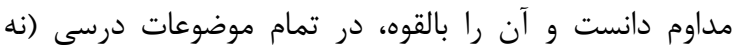
الزاماً در موضوع خاصى) به كار برد. رشد قواى خلاق، الندان انديشه

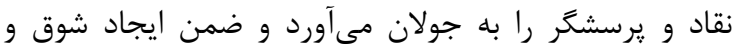
رغبت به يادكيرى، عرصه يادگيرىهاى درون كلاس را را به

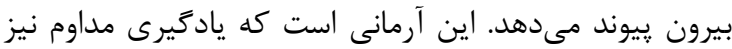
آن را دنبال مى كند (1) - (1).

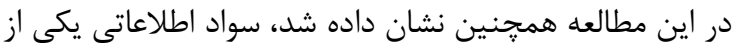
مهارتهاى مورد نياز يادگيرنده مادام العمر است كه در در برنامه

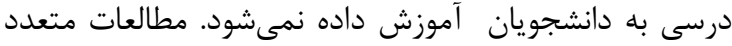
مىنويسند: سواد اطلاعاتى پايه و توسعه دهنده يادكيرى مادام العمر است و توانايى دانشجويان را در يِيدا كردن، استفاده، ارزيابى و مديريت اطلاعات افزايش مى دههد. قابليتهاى سواد إدان

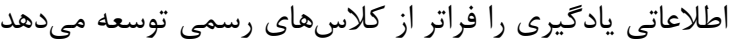

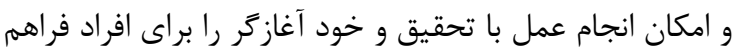

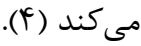
در مطالعه حاضر، زمينهسازهاى شكلَيرى يادگيرى مادام

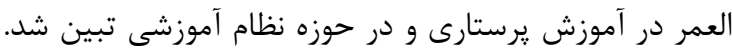

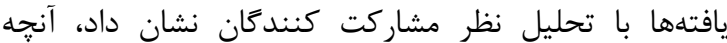

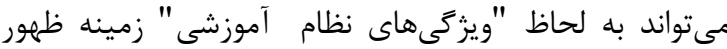

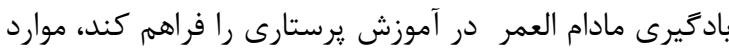

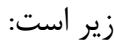
ديدكاه و نكَرش سياست كذاران و قانون كَاران دولتى و حوزه بهداشت ودرمان، نسبت به مفهوم يادكيرى مادام العمر؛ نكَرش و آكاهى مديران و اساتيد دانشخاه و نيز مديران مراكز درمانى بردي مانى و بالين؛ و همكارى بين سازمانهاى بهداشت ودرمان و وانيان

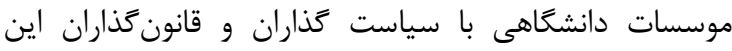
حوزه؛ به طورى كه يادگيرى مادام العمر بايد جزء اولويتهاى سياسى، سازمانى اين نهادها باشد و مديريت حامى و و آثاه با باديا همراهى اساتيد توانمند در مهارتهاى يادكيرى مادام العمر بتوانند زمينه و بستر شكل كيرى اين فرايند را در دانشجويان يرستارى فر اهم كنند. تغيير در هر برنامهاى در سطح كلان و ميانى كشور در مرحله اول نيازمند بينش سياسى مثبت در رابطه با موضوع مورد تغيير است و در مرحله بعد اراده سياسى براى انجام آن، منجر به تدوين قوانين و ابلاغ دستورالعملها در سطح وزرات خانه خواهد شد و در نهايت تعهد به ترويج موضوع مورد تغيير، به 


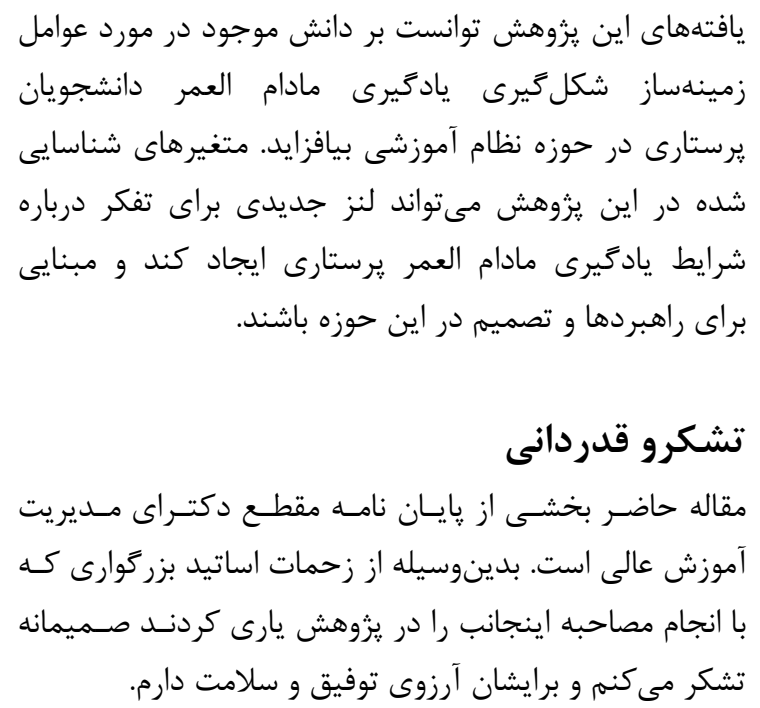

\section{REFERENCES}

1. Adabas A. Kaygin H. Lifelong learning key competence levels of graduate students. Universal Journal of Educational Research 2016;4: 31-38.

2-Kazu H, Demiralp D. Faculty members' views on the effectiveness of teacher training programs to upskill life-long learning competence. Eurasian Journal of Educational Research 2016; 63: 205-224.

3- American Association of Medical Colleges, \& American Association of Colleges of Nursing. Lifelong learning in medicine and nursing. Available from: http://www.aacn.nche.edu/education-resources/MacyRepor.

4 -Mi M, Riley-Doucet C. Health professions students' lifelong learning orientation: associations with information skills and self-efficacy. Evidence Based Library and Information Practice 2016;11:2-11.

5- Steelmant VM. Engaging in Lifelong learning to lead the Way. President's Message 2014; 99: 22-27.

6- Strauss S, Ed. Corbin G. Basics of qualitative research: techniques and procedures for developing grounded theory. 3rd ed. Translated by: Dehghan Nayari N, Fakhr Movahedi A, Esmaili M, Sadeghi T, Tayebi Z. Tehran: Andisheh Rafi Publications; 2012. [In Persian]

7-Iranian National Commission for UNESCO. Workshop on national education of novel concepts and systems in lifelong $\quad$ learning. $2013 . \quad$ [Cited 2015 January14] Available from: http://www.unesco.org/new/fileadmin/MULTIMEDIA/FIELD/Tehran/pdf/LLL11. [In Persian]

8- Baraz-Pordanjani SH, Memarian R,Vanaki Z. Damaged professional identity as a barrier to Iranian nursing students. J Clin Nurs Midwifery 2014; 3: 1-15. [In Persian]

9- Kermanshahi A. Parvinian AL. Barriers to implementation of evidence-based care: viewpoints of nursing staff. Iranian Journal of Medical Education 2012;12:92. [In Persian]

10- Bagherian B. Nursing mangers views of the educational hospitals of Kerman University of Medical Sciences regarding barriers of nurses' roles performance. The Journal of Urmia Nursing and Midwifery Faculty 2015; 13:28-33. [In Persian]

11- Moghadarikoosha M. Barriers of clinical education from nursing students' points of view. Scientific Journal of Hamadan Nursing and Midwifery Faculty 2016; 24:92-97. [In Persian]

12- Murdoch D, Whittle ES. Generic skills in medical education: developing the tools for successful lifelong learning. Medical Education 2012: 46: 120-28.

13-Yazdani Sh, Hosseini F, Akbari M. Educational quality, support document strategic document of qualitative development of medical education.2011. Available from: nkums.ac.ir/get_file.aspx?fn=Uploaded/Users/2/45/sposhtiban.pdf.

14- Heydari A, Soudmand P, Hajiabadi F, Armat M, Rad M. The causes and solutions of the theory and practice gap from nursing education view point: A review article. J Med Educ Dev 2014; 7:72-85. [In Persian]

15- Khodaei A, Mansourian M, Ganjei S, Asgari H. strategies for decreasing gap between theory \& clinical performance from the viewpoints of nursing students in Tabriz University of Medical Sciences. Research in Medical Education 2016; 8:49-59. [In Persian] 
16- Rassouli M, Zagheri Tafreshi M, Mohammadnejad E. Challenges in clinical nursing education in Iran and strategies. J Clin Exc 2014; 2: 11-22. [In Persian]

17- Rahimi A, Ahmadi F. The obstacles and improving strategies of clinical education from the viewpoints of clinical instructors in Tehran's nursing schools. Iranian Journal of Medical Education 2006; 5: 73-79. [In Persian]

18- Pourshafei H. Lifelong learning: sustainable education strategy. Pajouheshgaran 2007;13:r12. [In Persian]

19- Laal M, Salamat P. Lifelong learning; why do we need it? Procedia- Social and Behavioral Sciences. 2012; 31: 399403.

20- Shamsaee F, Alhani F, Cheraghi F. Education of critical thinking in nursing. Iranian Journal of Medical Education 2010; 10: 313-17. [In Persian]

21- Akhoundzadeh K, Ahmari Tehran H, Salehi S, Abedini Z. Critical thinking in nursing education in Iran. Iranian Journal of Medical Education 2011; 11:210-21. [In Persian]

22- Safabakhsh L, Jahantigh M. Clinical reasoning, new assessment index in the nursing students exam process. Journal of Strides in Development of Medical Education 2016;13: 525-27. [In Persian]

23- Nikmanesh Z, Shahinfar M. The role of caregiver burden in quality of life and perception of patients with chronic kidney failure on hemodialysis. Ann Mil Health Sci Res 2016; 14:e11465. 